УДК 75.056

ББК 85.14

DOI:10.18688/aa155-4-46

Chiara Ponchia

\title{
Suggestions from Antiquity. Discovering Classical Iconographies in the Trecento Divine Comedy lllustrations
}

The Divine Comedy is one of the masterpieces of Italian literature. It was written by the Florentine poet Dante Alighieri during the period spanning the early years of the $14^{\text {th }}$ century until his death in 1321. The poem describes the redemption journey made by Dante himself through the three realms of the Afterlife: Hell (Inferno), Purgatory (Purgatorio) and Heaven (Paradiso). It allegorically represents the path of the sinner soul through expiation and then towards God. To write his poem, Dante looked for inspiration both in medieval and classical culture. Therefore, during his pilgrimage to the Afterlife, Dante imagines himself meeting the great poets of antiquity, like Ovid, Horace, Lucan, and, above all, Virgil, who will be Dante's guide through Hell and Purgatory. In addition, Dante meets characters derived from the ancient mythology, such as Charon and Minos.

After Dante's death in 1321, the Divine Comedy quickly became one of the most appreciated works of that time [4, p. 176]. Its geographical distribution was impressively wide, and from the first half of the $14^{\text {th }}$ century patrons looking for visual support to imagine Dante's pilgrimage began asking for illuminated manuscripts of the poem. Illuminators were therefore faced with the difficult challenge of illustrating a text with no previous iconographic tradition. The easiest way to deal with this issue was to turn to other sources, choosing from among the most suitable iconographies to reuse in Dante's masterpiece. This phenomenon can be observed in the first illuminated manuscripts of the Divine Comedy produced in Northern Italy, the corpus selected as a case study to investigate the sources illuminators turned to when creating the first images for Dante's poem.

Particularly for the Inferno medieval art had much to offer the early illuminators of the poem. E.g., mosaics and frescoes could easily provide models for the devils, while punishments and hellish settings were often inspired from the sculpted Last Judgments on the tympanums of the churches and illuminations of sacred texts.

However, just as Dante's literary sources were both medieval and classical, the illuminators' quest for images was not limited to contemporary sources, and in some cases, the echo of Classical models in the Divine Comedy illustrations can be appreciated.

Curiously enough, this does not usually happen when it is specifically required from the text: e.g., Minos is never represented as the mythological king of Crete, but as a medieval devil. We can observe the same phenomenon if we consider the Minotaur, which only in one case out of nine is painted as the mythological monster, with a human torso and a bull's head. 
Illuminators seem to have turned to classical sources when they had to visualize something that was not clearly described by the author, like a setting or the structure of a scene.

In many illuminations depicting Hell, we find the representation of buildings or city walls. This iconography is suggested by Dante himself, who calls Hell the "città dolente", the "sorrowful city", while the lower part of Hell is called "Città di Dite", "City of Dis" or the "red city", because of the color of the flames. The idea of Hell as a fortified city could be suggested by other elements as well, for example the Gate of Hell, which in some cases is illustrated as a monumental portal inserted in a complex of city walls. To depict these "infernal architectures" illuminators took inspiration both from contemporary sources and from ancient ones.

The most interesting example we find in ms. 1102 of the Angelica Library in Rome. It contains illuminations only of the Inferno by Emilian illuminator, who was close to the manner of Bolognese painter Simone dei Crocifissi [3]. In this book, from the entrance of Dante and Virgil in the City of Dis to their arrival at the Malebolge, all the illuminated scenes are set inside city walls, seen from a bird's-eye view. Walls are drawn with an evident relish for realistic details, and we can appreciate different kinds of doors and towers. At f. $9 \mathrm{v}$ we find the first representation of the City of Dis as a fortified city: we can see the polygonal shape of the wall system, the round arch of the city gates and battlements at the top of the walls. This typology of fortified city is rooted in ancient models, where city environments were recalled by the succinct representation of a circular or polygonal wall system, sometimes with towers in it. A fascinating example of this representative cliché is offered by the Tabulae Iliacae, a group of twenty-two stone tablets showing scenes from literary works, mainly epic ones $\left[1\right.$, p. 26]. The Tabulae Iliacae were all produced in the $1^{\text {st }}$ century, and most of them are unfortunately fragmentary. In these works representations of the city walls seen from a bird's-eye view are very frequent, as we can observe in the Troy siege in the Tabula capitolina, one of the best-preserved samples of this production [15].

The idea of associating the image of the fortified citadel with the realm of Hell is truly ancient: in the Virgilius Vaticanus (Vatican City, Vatican Library, ms. 3225), the famous $5^{\text {th }}$ century manuscript of Virgil's Aeneid [20], Hades is represented as a fortified citadel, thus proving that this was an iconographic choice of a long-standing tradition.

The fortified citadel iconography was destined to survive throughout the Middle Ages. Thanks to Carolingian illuminators we find it perfectly preserved in a manuscript of the Corpus agrimensorum Romanum (Vatican City, Vatican Library, Pal. Lat. 1564), copied from an original of the $6^{\text {th }}$ century [17]. We also find the representation of the city walls with people inside and scenes taking place like in the Bible of Saint Paul Outside the Walls. It was in this flourishing artistic period that the fortified citadel iconography underwent significant changes: it was combined with another ancient pattern, the monumental arch used to frame the figures of Jesus, the evangelists and authors in general. We can further follow the development of the fortified citadel iconography in the Ottonian period, where once again we find the pattern of the fortified citadel mixed with the motif of an arch, as we can see in the precious illuminations of the gospel book of Otto III. This element survived in Romanesque art and in gothic art [14, pp. 191-194], thus keeping alive the memory of a centuries-old iconography.

Obviously, in ms. 1102 the ancient fortified citadel appears re-elaborated and up to date with contemporary models, real buildings and painted examples, but in its substance it is still connected with its ancient mold. 
The influence of antiquity can be detected in other elements as well. In chapter XI of the Inferno Dante and Virgil stop in front of the tomb of pope Anastasius II, who is condemned to spend eternity in a sarcophagus because of his heretical ideas. In the corresponding illumination in ms. 1102, Anastasius's sarcophagus is clearly inspired by a classical one. More precisely, the illumination depicts a sarcophagus of the so-called "chest" typology, originating from Constantinople and documented in Ravenna for all the Early Middle Ages [7, p. 360]. If we look for examples in the same geographical area of realization of ms. 1102, the Emilia region, we should consider the San Zama tomb, a Paleochristian sarcophagus set ab antiquo in the Saint Stephen complex in Bologna [2, p. 39, figg. 1-2] that the illuminator of ms. 1102 could have seen.

Extending our analysis to other Northern Italy Divine Comedy manuscripts, we can observe other cases of illuminations inspired from ancient models.

Let us consider ms. 33 of the Budapest University Library, also known as Codex Italicus, illuminated in the fifth decade of the $14^{\text {th }}$ century in Venice for the noble Emo family [5]. Ms. 33 is illustrated only in the Inferno and in the first chapters of the Purgatorio. In chapter XIII of the Inferno, Dante and Virgil cross the Forest of Suicides, a dark forest formed by the souls of suicide victims transformed into trees. When Dante tries to break a little twig, blood comes out of it and the trunk starts crying. Dante describes this place of sorrow saying that "the foliage was not green, but a dusky color; the branches were not smooth, but warped and knotted; there were no fruits there, but poisonous thorns" (Inf., XIII; vv. 4-6). Illuminators of Northern Italy Divine Comedy manuscripts are always faithful to this clear description, and usually the Forest of Suicides is painted as the gloomy place described by Dante, but in the Codex Italicus we find an interesting exception. Here the Forest of Suicides is illustrated with green and thriving trees; Dante is represented while breaking a small branch, bewildered by the blood spurt. This is a deviation from Dante's words and from the most frequent illustrative choice and can be understood by hypothesizing the influence of another iconographic tradition. In this case, this ancient model can be easily recognized in the very same source that inspired Dante for this chapter, that is to say the Aeneid description of the encounter between Aeneas and Polydorus. In the third book of the Aeneid, while looking for branches and leaves to decorate the sacred altars, Aeneas happens to break a twig, and some blood comes out of it while a voice starts crying: it is the soul of Polydorus, that is inhabiting a tree because his body lies without having buried. In the Virgilius Vaticanus this scene is represented in a tabula picta with Aeneas in front of a tree with green leaves and blood coming out of its branches. We can, therefore, presume that the illuminator of the Codex Italicus, in need for models to paint the Forest of Suicides, turned to an illuminated lost manuscript of the Aeneid, not too different from the Virgilius Vaticanus.

But the most interesting case is represented by the work of an Italian anonymous illuminator, the so-called Master of the Paduan Antiphonaries [13; 18]. This artist, who worked in Bologna and Padua, derives his name from a six-volume Antiphonary currently held in the Capitolare Library of Padua. Scholars think that these six manuscripts can be related to the document in the Padua Capitolare dated 1306, which refers to a man named Gerarducius who had to report to the sacristan Bottazzo how he employed a large amount of money that he received for an Antiphonary to deliver completed and fully decorated [13, p. 553]. 
The six manuscripts are particularly interesting because they show the immediate reception of the frescos of the Paduan Scrovegni Chapel, that Giotto had completed just one year earlier. The analysis of the illuminations reveals that not only had the Master of the Paduan Antiphonaries reflected on Giotto's quest for realism and three-dimensional painting, but that he also took direct inspiration from Giotto's characters and iconography.

After this stunning work, the Master of the Paduan Antiphonaries carried on his career collaborating with Bolognese illuminators in different kinds of illuminated books, namely legal manuscripts and manuscripts with narrative texts. At the beginning of the fourth decade of the $14^{\text {th }}$ century, the Master illuminated a Roman de Troie, currently held in the National Library of Austria (ms. Cod. 2571). In this beautiful book, the Master realized more than 197 illuminations, where he still shows his debt towards Giotto's art, but also an update on the Bolognese gothic innovations. Afterwards, we find the Master involved in the decoration of another amazing work, the Roman de Troie of the National Library of Russia in Saint Petersburg (Fr.F.v.XIV.3), which he illuminated in cooperation with two other artists [11]. Russian Roman de Troie is embellished by 347 illuminations, an impressive number of images that makes this Roman the most fully-illustrated one among the extant manuscripts of this literary work.

Probably after the conclusion of Russian Roman de Troie, the Master of the Paduan Antiphonaries started work on his last known manuscript, the Divine Comedy Egerton 943 of the British Library of London.

The Egerton 943 is a parchment manuscript, realized in Padua or, more likely, in Bologna in the second half of the fourth decade of the $14^{\text {th }}$ century. It bears 261 illuminations, and it is the first manuscript of the Divine Comedy, whose illustrative system involves all the main parts of the poem, Hell, Purgatory and Heaven, from the first chapter of the Hell until the last chapter of the Heaven.

To succeed in the difficult endeavor of visualizing Dante's entire poem, the Master of the Paduan Antiphonaries turned to all the artistic inputs he had collected in his life, first of all to Giotto's and the Bolognese's legal manuscript illuminations. Therefore, in the Egerton 943 we can appreciate hundreds of beautiful images realized with grotesque realism. From the Scrovegni frescos the Master also derived evident pleasure in creating stories with images, just like Giotto did in his masterpiece. From Bolognese illumination the Master derived some peculiar elements, like the small decorated buildings used to create the setting, and the idea of structuring the scene in different units through a system of round arches.

However, in addition to all the mentioned elements, a deeper analysis of the Egerton illuminations reveals that the Master of the Paduan Antiphonaries not only took inspiration from contemporary sources, but he was also influenced by ancient models.

Let us consider some examples.

To illustrate the heavens in many Paradiso illuminations the Master adopted the same structure, with Dante and Beatrice in the left part of the image, while the blessed souls are drawn in the right part of the composition, inserted in a segment of sky framed by arches painted in different shades of blue (Ill. 75). This motif of the "segment of sky" is rooted in a century-old and well-established iconographic tradition. There are many examples, so I will choose just a few to retrace in short the story of this iconography. 
Despite the fire of 1823, we still know how the Paleochristian frescos of Saint Paul outside the walls in Rome looked like, thanks to some watercolor copies held in the Vatican Library (Barb. Lat. 4406) [9]. Thanks to these precious copies, we know that two painted scenes presented the "segment of sky". The same iconography appears quite frequently in the Octateuchs books studied by Weitzmann [19], particularly in ms. 602 of Mount Athos Vatopedi monastery, in the formerly ms. A.1 of the Library of the Evangelic School of Smyrna, in ms. G.I.8 of the Topkapi Library and in the Greek mss. 746 e 747 of the Vatican Library, which are dated from the $11^{\text {th }}$ to the $12^{\text {th }}$ century. Weitzmann did not fail to notice this recurring element, so he drew the conclusion that "as a rule, in the Octateuchs God is depicted as a hand reaching out of a segment of sky".

For us even more relevant are the illuminations where the "segment of sky" is increased and we see not only the divine hand but God half-length, as it is common in the illustration of Genesis 17:4-5, when God makes Abraham father of many nations. This composition amazingly resembles some of the Master's illuminations, both in the Paduan Antiphonaries and in Egerton 943. If we compare the illumination of f. 70r in the Paduan Antiphonary B14 and the Smyrna illumination where God appears to Abraham and Sarah, we notice many surprising analogies: the thick segments that frame the portion of sky, the way the divine character is portrayed, half-length and with special attention paid to the arms that come out from the space of the segment of sky and stretch towards the worshipping figures.

Although it is hardly conceivable that the Master of the Paduan Antiphonaries could see Paleochristian Bible or Byzantine Octateuch, this hypothesis should not be fully rejected. Medica proposed that a certain amount of Greek manuscripts must have been in Bologna in the last years of the $13^{\text {th }}$ century, because the Bolognese illuminator called Gerona Master shows in his works some faithful copies of Palaeologan models [12, p. 129]. Furthermore, the scholar pointed out that both Bolognese Franciscans and Dominicans had always been in contact with Constantinople [12, p. 129]. Besides, we must consider the presence in Bologna from 1287 of Armenian monks community, who has its own monastery, probably with a library and a scriptorium, as we can assume from Armenian illuminated codex (Erevan, Matenadaran, ms. 2705) whose colophon reports that it was made in Bologna at the end of the $13^{\text {th }}$ century $[12$, pp. 129-130]. Therefore, nothing rules out the possibility that during his collaboration with Bolognese illuminators the Master of the Paduan Antiphonaries could have been exposed to a repertory of Byzantine models, if not to some Byzantine manuscripts.

In addition, it is also possible that the Master of the Paduan Antiphonaries knew some intermediate models. In fact, like many other ancient models, the "segment of sky" motif was never forgotten during the Middle Ages, and it survived through many copies and re-elaborations. A High Middle Ages example is offered by the San Marco Genesis mosaics, whose subjects were copied from the famous Cotton Genesis or a similar manuscript ${ }^{1}$, and where we find once again the "segment of sky".

\footnotetext{
1 J.J. Tikkanen was the first to notice the strict connection between the San Marco mosaics and the Cotton Genesis illuminations, suggesting that the craftsmen used the illuminations as a direct model [16]. Tikkanen's thesis was generally accepted in the following studies, although some scholars preferred to hypothesize the existence of an intermediate model [6], or the existence of a lost twin manuscript, that was the one effectively used by the San Marco craftsmen [10].
} 
Finally, we can identify another reference to the antiquity in some of the Paradiso images, where Dante, set in the left part of the composition, faces forward while talking with the saints, represented as hanging heads in the segment of sky. Such a unique representation has no comparison in the contemporary artistic production, but we can find its ancestor in the well-known Seven Sisters illumination in the Leiden Aratea (University Library, VLQ 79), a Carolingian masterpiece which is a copy of a lost classic model [8].

In the Aratea, just as in the Egerton illumination, we can see some wavering heads against a deep blue background, each of them turned in a slightly different direction. In the Aratea, heads emerge from a sort of small dark cloud that links the neck to the background, while in the Egerton manuscripts the necks are linked to the background by golden strokes.

It is difficult to believe that the Master of the Paduan Antiphonaries could have studied a classical or Carolingian illuminated manuscript, although it cannot be ruled out. However, we can hypothesize that the Master was familiar with some intermediate copy. In the case of the Seven Sisters, he could have been familiar with this particular iconography because of Roman floor mosaics, where Seasons could be represented half-length or simply as fluctuating heads.

In conclusion, the examples we have seen demonstrate that at the end of the Middle Ages, ancient models were still very much alive. We do not know to what degree mediaeval artists were aware of using such a long-standing repertoire, but they did not find strange to use it when illustrating a $14^{\text {th }}$ century text, deeply related to the mediaeval culture and mentality, such as the Divine Comedy.

Title. Suggestions from Antiquity. Discovering Classical Iconographies in the Trecento Divine Comedy Illustrations.

Author. Chiara Ponchia - Ph. D., Postdoctoral Research Fellow. University of Padua. Piazza Capitaniato 7, 35139 Padova, Italy. ponchiachiara1@gmail.com

Abstract. After Dante's death (1321), the Divine Comedy quickly became one the most appreciated works of Italian literature. Its spreading was impressively wide, since from the first half of the $14^{\text {th }}$ century patrons asked for illuminated manuscripts of the poem, looking for a visual support to imagine Dante's pilgrimage through the Hereafter. Therefore, illuminators had to face the difficult challenge of illustrating the text with no previous iconographic tradition. The easiest way to deal with this issue was turning to other sources, choosing among them the most suitable iconographies to be re-used in Dante's masterpiece illustration. In this article we will see that, just as Dante's literary sources were both mediaeval and classical, the illuminators' quest for images wasn't limited to contemporary sources, and in some cases we might find the echo of Classical models in the Divine Comedy illustrations.

Keywords: history of illuminated manuscripts; Divine Comedy; Italian illumination; mediaeval art; iconography and iconology; Classical heritage.

Название статьи. Рекомендации из античности: открытие классической иконографии в иллюстрациях к «Божественной комедии» эпохи треченто.

Сведения об авторе. Понкья Кьяра - Ph. D., научный сотрудник. Университет Падуи, Piazza Capitaniato 7 , Падуя, Италия. 35139. ponchiachiara1@gmail.com

Аннотация. После смерти Данте в 1321 г. «Божественная комедия» очень быстро стала одним из наиболее признанных произведений итальянской литературы и получила весьма широкое распространение. Начиная с первой половины XIV в. заказчики манускриптов требовали, чтобы текст сопровождался миниатюрами, изображающими путешествие Данте по загробному миру. В результате иллюстраторы столкнулись со сложной задачей оформления текста, не имевшего в прошлом иконографической традиции. Самым простым способом справиться с проблемой был поиск и использование наиболее подходящей иконографии из других источников. Автор статьи отмечает, что подобно тому, как Данте находил источник своей поэзии и в средневековой, и в античной традиции, так и иллюстраторы в поисках нужного образа пользовались не только современными им источниками. В некоторых случаях можно говорить об отголосках античных образцов для иллюстраций к «Божественной комедии».

Ключевые слова: история иллюстрированных рукописей; «Божественная комедия»; итальянская миниатюра; средневековое искусство; иконография и иконология; наследие античности. 


\section{References}

1. Bianchi Bandinelli R. Hellenistic-Byzantine miniatures of the Iliad (Ilias Ambrosiana). Olten, Urs. Graf-Verlag Publ., 1955. 182 p.

2. Cecchi Gattolin E., Il santuario di Santo Stefano in Bologna, Modena, Poligrafico Artioli, 1976. 178 p. (in Italian).

3. Ciardi Dupré M. G. Miniatore bolognese (“Jacobus”?). Fioritura tardogotica nelle Marche: Catalogue. Milano, Electa Publ., 1998, no. 7, pp. 74-76 (in Italian).

4. Ciociola C. Dante, in La tradizione dei testi. Milano, Il sole 24 ore Publ., 2005, pp. 137-199 (in Italian).

5. Dante Alighieri. Commedia. Biblioteca Universitaria di Budapest: Codex italicus 1, 2 vols. Verona, Università degli Studi di Verona, 2006 (in Italian).

6. Demus O. Die Mosaiken von San Marco in Venedig, 1100-1300. Baden bei Wien, Rohrer, 1935. 107 p. (in German).

7. Farioli Campanati R. Sarcofago. Enciclopedia dell'Arte Medievale, vol. X. Roma, Istituto dell'Enciclopedia Italiana Publ., 1999, pp. 359-373 (in Italian).

8. Katzenstein R.; Savage-Smith E. The Leiden Aratea: ancient constellations in a medieval manuscript. Malibu, Calif, J. Paul Getty Museum Publ., 1988. 36 p.

9. Kessler H. L. Copies of the frescoes of S. Paolo fuori le Mura, Age of Spirituality. Late Antique and Early Christian Art, Third to Seventh Century: Catalogue. New York, The Metropolitan Museum of Art Publ., 1977, pp. 488-489.

10. Koshi K. Die Genesisminiaturen in der Wiener "Histoire Universelle" (cod. 2576). Wiener kunstgeschichtliche Forschungen, vol. 1. Wien, Holzhausen Publ., 1973. 56 p. (in German).

11. Mauro A. (ed.). El Codice de la Guerra de Troya. Libro de Estudios ( El Roman de Troie ). Saint Petersburg - Madrid, Russia National Library Publ. - A Y N Publ., 2004. 331 p. (in Spanish).

12. Medica M. La città dei libri e dei miniatori. Duecento. Forme e colori del Medioevo a Bologna: Catalogue. Venezia, Marsilio Publ., 2000. 426 p. (in Italian).

13. Medica M. Maestro degli Antifonari padovani. Dizionario biografico dei miniatori italiani. Secoli 9-16. Milano, Sylvestre Bonnard, 2004, pp. 447-448 (in Italian).

14. Pächt O. La miniatura medievale. Un'introduzione. Torino, Bollati Boringhieri Publ., 1987. 222 p. (original edition: Buchmalerei des Mittelalters. Eine Einführung. Monaco, 1984) (in Italian and German).

15. Salimbene C. La Tabula Capitolina. Bollettino dei Musei Comunali di Roma, 2002 (2003), no. 16, pp. 5-33 (in Italian).

16. Tikkanen J. J. Die Genesismosaiken von S. Marco in Venedig und ihr Verhältnis zu den Miniaturen der Cottonbibel. Nebst einer Untersuchung über den Ursprung der mittelalterlichen Genesis darstellung besonders in der byzantinischen und italienischen Kunst. Acta Societatis Scientiarum Fennicae, no. 17. Helsingfors, Druckerei der Finnischen litteratur-gesellaschaft Publ., 1889. 153 p. (in German).

17. Toneatto L. Corpus agrimensorum Romanorum. Vedere i Classici. L'illustrazione libraria dei testi antichi dall'età romana al tardo medioevo: Catalogue. Roma, F. lli Palombi Publ., 1996, no. 9, pp. 177-182 (in Italian).

18. Toniolo F. Il Maestro degli Antifonari padovani: prassi e modelli. Medioevo: le officine. Milano, Electa Publ., 2010, pp. 549-562 (in Italian).

19. Weitzmann K.; Bernabò M. The Byzantine Octateuchs The illustrations in the manuscripts of the Septuagint, 2 Oktateuch. Princeton, Department of Art and Archaeology, Princeton University Publ., 1999.

20. Wright D. H. Virgilio, Opere, Vedere i Classici. L'illustrazione libraria dei testi antichi dall'età romana al tardo medioevo: Catalogue, Roma, F. lli Palombi Publ., 1996, no. 1, pp. 141-149 (in Italian). 